\title{
Why Was There Even a Reformation in Lindau? The Myth and Mystery of Lindau's Conflict-Free Reformation
}

\author{
JOHANNES WOLFART \\ Carleton University
}

Histories of Lindau emphasize a remarkably conflict-free course of early reform in that particular locale. This view is established and maintained by multiple means, including hyper-credulity towards the peacefulness asserted by local authorities, anachronistic projections of the confessional "compromise" that was the Tetrapolitana back into the 1520s, and a deliberately narrow definition of key subjects, to exclude obvious contrary evidence. While Bernd Moeller has recently remarked that Lindau society was so harmonious that it is surprising there was any Reformation at all, archival sources actually indicate conflict in several areas pertaining to the early Reformation in Lindau, including interpersonal violence over key theological issues, the social conflict of the Peasant's War, and stark communal divisions over iconoclasm, resulting in the ritual conflict of a feud. This article is both a particular historical corrective and a general historiographical illustration of how mythographic and historiographic modes may be entangled in early Reformation studies.

Les ouvrages d'histoire montrent un début de Réforme remarquablement exempt de conflit dans l'histoire de Lindau. Cette interprétation fut établie et renforcée de plusieurs façons, dont une excessive crédulité envers les assertions de paix faites par les autorités locales, la projection anachronique de l'esprit de compromis confessionnel propre au Tetrapolitana de 1520, ainsi que la restriction délibérée des définitions de certains sujets essentiels, menée afin de réduire les contradictions patentes. Bien que Bernd Moeller ait récemment fait remarquer que la société de Lindau apparaît comme si harmonieuse que l'on peut s'étonner qu'il s'y soit même déroulé une Réforme, les documents d'archives révèlent plutôt l'existence de conflits dans plusieurs secteurs de Lindau au début de la Réforme, conflits prenant la forme, par exemple, de violences entre interlocuteurs lors de discussions sur des questions théologiques centrales, de conflits sociaux participant de la Guerre des Paysans, et de sérieuses divisions marquant la communauté au sujet de l'iconoclasme, ayant pour résultat un échange formel de représailles. Cet article cherche donc à la fois à corriger l'histoire et à mettre en lumière, par ce cas de figure, comment les usages mythographiques et historiographiques s'enchevêtrent et marquent les études des débuts de la Réforme.

\section{Introduction}

$\mathrm{T}$ he approximately eighty-five imperial cities that once dotted the German countryside have long fascinated students of the early Reformation. ${ }^{1}$ It

1. The estimate is that of Bernd Moeller, Imperial Cities and the Reformation: Three Essays, ed. and trans.

H. C. Erik Midelfort and Mark U. Edwards, Jr. (Philadelphia: Fortress Press, 1972), 41. 
is widely held that the imperial city of Lindau stood apart from the majority of these cities for two reasons. First, Lindau was unique in its geography. Topographically, the city occupied an island in Lake Constance, ${ }^{2}$ which also located it at the intersection of two man-made frontiers: a line dividing the Austrian lands from the rest of the Holy Roman Empire and a line separating the Swiss Confederacy from other German-speaking lands. By 1530, this border location gave rise to a second unusual feature: Lindau's commitment (along with Strasbourg, Constance, and Memmingen) to a confessional statement known as the Confessio Tetrapolitana. Historians of Lindau's Reformation have made much of this deviation from what would become the dominant confessional norm, and have often plotted something of a Lindavian Sonderweg through the whole of the Reformation. ${ }^{3}$ Yet, one should beware the tendency to read complex texts or entire cultures with an eye only to their most outstanding and exotic features. This, as Roger Keesing cautioned so long ago, can actually lead to mis-readings of the whole text/culture or, in this case, a significant distortion of the overall historical situation. ${ }^{4}$

In fact, in most other regards Lindau was a very ordinary German town of its time. Its relatively small size put it in a class quite apart from celebrated metropolises like Augsburg, Strasbourg, Zurich, or Constance. Instead, Lindau's citizens and inhabitants had much more in common with the people in the nearby towns of Isny, Wangen, or even Bludenz. Though this would not sit well with the patriots of nineteenth-century citizens' Vereine, or with the boosters of twenty-first-century chambers of commerce, all-in-all early modern Lindau sat deservedly close to the verge of relegation from the second to third divisions in the league tables of German cities and towns. ${ }^{5}$

2. Where Anglicized names for German places are in common use (e.g., Lake Constance for Bodensee, or Nuremberg for Nürnberg) these have been used in place of German ones.

3. Classically, see J. D. Marte, Die auswärtige Politik der Reichsstadt Lindau, 1530-1532 (Heidelberg: n.p., 1904); recently, see the special issue Die Reformation in Lindau [=Neujahrsblatt 47 des Museumsvereins Lindau] (Lindau: Museumsverein Lindau, 2007).

4. Roger M. Keesing, “Exotic Readings of Cultural Texts," Current Anthropology 30 (1989): 459-69; Keesing points out that career concerns are prominent among the inducements to such academic exoticism.

5. For discussion of the cultural horizons of Lindau's inhabitants, see Johannes C. Wolfart, "Global Yokels: Vernacular Manuscript Chronicles and Urban Identity in Early Modern Germany," in City Limits: Perspectives on the Historical European City, ed. G. Clark, J. Owens, and G. T. Smith (Montreal and Kingston: McGill-Queen's University Press, 2010), 65-87. 
Still, historiographically the Tetrapolitana has cast a very long shadow over the Lindau Reformation - and in two directions, both forwards and backwards. Yet, to consider the Tetrapolitana as a peculiarity at all is to avail oneself of the benefits of hindsight from the point of view of confessional Lutheranism. Certainly, by the early seventeenth century, and especially on the eve of the Thirty Years' War, many Lindauers viewed the Tetrapolitana with a measure of buyer's remorse. When they first submitted the document to the emperor Charles V, however, they surely had no expectation that they would thereby be further isolating themselves from a confessionalized empire. On the contrary. In its own day, the Tetrapolitana was simply an instrument of association with the largest possible group of other German and Swiss polities. Subject to the twin pressures of imperial politics and super-regional commercial relations, a small border town like Lindau had to find a way to turn Swiss without actually turning Swiss: to be Swiss-ish. ${ }^{6}$ At the end of the turbulent 1520s, the Tetrapolitana appeared to Lindauers as the best way to do that.

Historically, therefore, it makes little sense to project characteristics subsequently extracted from the story of the Tetrapolitana back onto Lindau in the 1520s. Yet that is exactly what appears to have happened, at least in local histories. Thus, compromising or equivocating aspects of the Tetrapolitana have been generalized into an image of Lindauers as compromisers in all things, as diplomatic by nature and, especially, as capable of an unusually conflict-free Reformation. ${ }^{7}$ Indeed, relying perhaps too much on this mythic portrayal of pacific reform, Bernd Moeller has recently remarked that it is something of a puzzle or mystery that the Reformation took hold at all in Lindau, especially at such an early stage, given the prosperous and overall harmonious state of Lindau

6. See Thomas A. Brady, Jr., Turning Swiss: Cities and Empire 1450-1550 (Cambridge: Cambridge University Press, 1985).

7. For a comparative characterization of the Lindau Reformation as balanced (neutral) in its inception and steady (stetig) in the long term, see Martin Brecht and Hermann Ehmer, eds., Südwestdeutsche Reformationsgeschichte: Zur Einführung der Reformation im Herzogtum Württemberg 1534 (Stuttgart: Calwer Verlag, 1984), 165. The most recent local historiography continues to emphasize Lindauers' propensity for clever diplomacy (geschickter Diplomatie) over the entire course of the long Reformation, from its Tetrapolitan inception, through the Interim of 1548, to the end of the Thirty Years' War. For example, see Otto Mayr, Die schwedische Belagerung der Reichsstadt Lindau 1647: Der Dreißigjährige Krieg am Bodensee und in Oberschwaben [= Neujahrsblatt 53 des Historischen Vereins Lindau] (Munich: Allitera, 2016), esp. 15-16. 
society. ${ }^{8}$ In part, Moeller's perspective was guided by his focus on the very few published controversial sermons-there are only two-from Lindau for the period before $1530 .{ }^{9}$ What follows considers more plentiful but less readily accessible archival sources. Such archival evidence considerably complicates Moeller's view of low conflict and high social stability in Lindau. In fact, Lindau was quite far from realizing Moeller's ideal of a Corpus Christianum. Thus, moreover, her early Reformation turns out to be no mystery at all, at least not historically. Indeed, as will be shown, there was plenty of conflict in Lindau in the 1520s, much of it of the type commonly associated with the early Reformation in its so-called Wildwuchs phase. Such conflict, however, is easily obscured by the conflation of Reformation histories with Reformation myths.

Reformation mythography and Reformation historiography each originated within the bounds of the so-called "long Reformation." Since then, their respective developments have entailed considerable close contact and substantial co-evolution. For example, Donald Kelley once celebrated Johannes Sleidanus as "one of the greatest of all modern historians" and argued that, notwithstanding personal passion and confessional allegiance, his historiography was properly "professional" in most regards. ${ }^{10}$ Of course, many contemporaries of Sleidanus's also produced a range of accounts of the Reformation which were just as overtly mythical; that is, they engaged in Reformation mythography. Conversely, Bob Scribner once observed (on the occasion of the celebration of the quincentenary of Luther's birth) that the practice of Reformation mythography remained as alive and well in his own day as it had been in Luther's. ${ }^{11}$ More recently, Amy

8. "Dass die Reformation in Lindau frühzeitig Fuß gefasst hat, lässt sich von den gedeihlichen und insgesamt harmonischen Zuständen, die hier herrschten, kaum herleiten." Bernd Moeller, "Die Confessio Tetrapolitana als Station der Lindauer Reformation," in Die Reformation in Lindau, 43-62, 45. 9. Michel Hug, Ain Kurtzer aber Christlicher unnd fast nutzlicher Sermon von dem rechten waren und lebendigen Glauben ... (Augsburg, 1524), digital copy available from the Bayerische Staatsbibliothek, Munich. The man often credited as the Reformer of Lindau, Thomas Gassner, preached at the disputation of Bern in 1528, so his sermon was not even heard in Lindau. It was printed by Froschauer at Zurich along with the proceedings of the disputation. On Gassner, see Karl Heinz Burmeister, Thomas Gassner: ein Beitrag zur Geschichte der Reformation und des Humanismus in Lindau [=Neujahrsblatt 21 des Museumsvereins Lindau] (Lindau: Museumsverein, 1971).

10. Donald R. Kelley, "Johann Sleidan and the Origins of History as a Profession," Journal of Modern History 52 (1980): 573-98.

11. R. W. Scribner, The German Reformation (London: Macmillan, 1986), 1-5 (“Some Reformation Myths"). 
Burnett has taken up the challenge of identifying a particular and enduring Reformation myth to offset the significance of her own historical account. ${ }^{12}$ For all the differences in their approaches-and they are considerable-Kelley, Scribner, and Burnett share a certain skepticism as regards the presumption that such entanglements of mythography and historiography are a thing of the past. Furthermore, they see it as unlikely that mythography and historiography would be disentangled simply as a function of ineluctable progress from early modernity to consummate high modernity. Therefore, in view of the fact that it is unlikely to happen otherwise, many scholars-including the three mentioned above-still consider such disentanglement of myths and histories as a deliberate aim or primary task of scholarship.

A slightly different approach to Reformation narratives, past and present, is that currently pursued by scholars of early modern memorial cultures. ${ }^{13}$ This is a diverse group; yet what scholars working in this vein all share is the eschewal of terminology juxtaposing myth and history. Furthermore, for many of them it is emphatically not the case that a circumscription of Reformation mythography and historiography within the bounds of a singular memorial culture precludes the possibility in principle of a general differentiation of myth from history. Notwithstanding such differentiability, mythography and historiography co-existed in the past more than just incidentally, or in the manner of synchronic but parallel trajectories. Rather, as historical modes of knowing the Reformation, mythography and historiography intersected and interacted in complex and powerful ways. Thus, to trace the difference between myth and history through the tangled web of their interactions remains an important task of all scholarship of memorial cultures, whether it is selfconsciously confessional, post-confessional, primarily theological, historical, post-modernist ... whatever. Therefore, the purpose of what follows includes, in addition to a particular corrective to the history of one place, consideration

12. Amy N. Burnett, "The Myth of the Swiss Lutherans: Martin Bucer and the Eucharistic Controversy in Bern," Zwingliana 32 (2005): 45-70.

13. For diverse examples, all pertaining to Lutheran memorial culture, see Robert Kolb, Martin Luther as Prophet, Teacher, and Hero: Images of the Reformer, 1520-1620 (Grand Rapids: Baker Books, 1999); Susan Boettcher, "Lutherans as a Community of Memory," in Defining Community in Early Modern Europe, ed. Michael J. Halvorson and Karen E. Spierling (Aldershot: Ashgate, 2008), 121-41; Ulinka Rublack, "Grapho-Relics: Lutheranism and the Materialization of the Word," Past and Present 206 (2010): 144-66; Michael J. Halvorson, “German Lutheran Centennial Dramas," Lutheran Quarterly 30 (2016), 276-306. 
of whether similar "effects" extend well beyond Lindau and its history. This purpose is broadly "historiographical-critical" as well as narrowly corrective. Ultimately, the myth of Lindau's pacific Reformation depends on very particular historiographical practices. These serve to support or perpetuate certain myth-derived expectations about the course of reform or the nature of the Reformation by virtue of inclusion or exclusion of key data. Simply put, the claim that the Lindau Reformation was conflict-free depends entirely on how scholars have chosen to define all three terms of the proposition: Lindau, Reformation, and conflict. Moreover, such practices of selection by definition are not limited to local historiography. Indeed, one suspects that they remain widespread in historical Reformation studies in various locales, as well as on regional, national, and international scales.

\section{The definitions game}

To begin with, then, there are several possible ways to define, in the literal sense of drawing borders, the Lindau of the 1520s. When contemporaries spoke of Lindau they meant the jurisdiction of the council in representing its citizens, in accordance with a host of historical practices and privileges. Infamously, however, there was more than one such jurisdiction. Thus, one border of Lindau was marked by the city walls, which closely followed the shore of the island. This was a very visible boundary of the so-called "higher jurisdiction" exercised by the council over criminal matters. In practice, however, many individuals subject to such higher jurisdiction commonly resided primarily beyond this boundary. Nevertheless, historians have often assumed an essential concentration of jurisdictional power "on the island," much as physicists commonly assume a "point mass" to describe and analyze certain physical interactions. Another Lindau border circumscribed a much larger territory on the mainland. By the early sixteenth century, this border was set with stone markers bearing the linden tree emblem of the city of Lindau, and encompassed a significant peasant population, including four tributary villages (Kellnhöfe) as well as other settlements. ${ }^{14}$ In this mainland territory,

14. In 1520, the Lindau government and the neighbouring count of Montfort contracted to renovate such stones marking the boundary between the city's mainland territory and Montfort lands. The contract confirmed a similar agreement from 1476, which was also excerpted. This excerpt includes a detailed topographical description. Stadtarchiv Lindau (StAL), Reichstädtische Akten (RA) AIII 
the Lindau council exercised the so-called "lower jurisdiction" to levy taxes. In return, many inhabitants of this zone enjoyed semi-citizen status as Beisassen. Some of Lindau's more prominent citizens also maintained estates, including primary residences, here. Thus, this territory contained what was probably a somewhat more heterogeneous resident population-especially in terms of wealth and status - than did the island. Finally, through one of several endowed institutions it administered, the council also claimed control over a population living beyond the physical limits of the low jurisdiction, much as it was also responsible for its own citizens living abroad. Clearly, therefore, whether one defines Lindau by its city walls and/or its higher jurisdiction or by the marked border of its lower jurisdiction makes a significant difference to the estimation of conflict in Lindau, or whatever else might belong or not belong to the history of Lindau. As we shall see, the established practice of considering only the walled city and the high jurisdiction (a tendency further encouraged by the fact that Lindau kept different kinds of records for each level of jurisdiction, and that this distinction has persisted in archival management) has an effect on estimates of conflict comparable to the outcome one might expect if one calculated crime rates for modern Paris without counting the banlieues, or for Chicago only in consideration of the Loop and the Near North Side. Yet that is exactly what the conventional historiography has done.

Chronological definition of the Reformation has had a similarly significant effect on the perception of conflict in relation thereto. It has been the habit of historians of Lindau to focus on the formal abolition of the Mass by order of the Lindau council in 1528 as the starting point of the Reformation. This obviously removes many mid-decade conflicts from the history of the Lindau Reformation. A further and related perspective considers the actual submission of the Tetrapolitana to the emperor as the moment at which religious conflict became a factor in Lindau's history, because this was the moment Lindau entered the conflict writ large, the one that supposedly shattered an otherwise united Christendom and a harmonious regional situation. Thus, conflict is seen primarily as a consequence of the introduction of the Reformation. Both perspectives remain prominent in the most recent historiography of the

43, 1 “Nidere Gerichtsmarken zwischen Montfort Auß den Vertrag dess Anno 1476 gezogen” (Lower jurisdiction boundary markers between Montfort [and Lindau] taken from the contract for the year 1476). Translations are mine unless otherwise noted. 
Lindau Reformation. ${ }^{15}$ Ironically, it is an older and more theologically oriented historiography that situates the formal start of the Lindau Reformation in 1525, with the decisive step of offering communion in both kinds in the parish church of St Stephan's. ${ }^{16}$ Even before then, of course, the arrival, communal vocation, and governmental toleration of three key evangelical preachers in Lindau in the first half of the decade (two died prematurely mid-decade, probably from plague) may also be taken as a key development; indeed, it is from their presence that the claim of a very early Reformation in Lindau derives. Thus, a chroniclerhistorian of Lindau writing in the first decades of the seventeenth century chose as his point of departure ab instaurato Evangelio Anno Domini $1522 .{ }^{17}$ Finally, the minutes of the Lindau council for 1519-22 indicate that a man named Clas Schmidlin was prosecuted as early as 1518 for "putting about writings, which had been highly forbidden [him].” The rhetorical form of this particular entry connects it to the preceding record of a prosecution for "blasphemy and swearing," a link that implies an emergent class of council business dedicated to managing religious unrest. Together, therefore, these two entries offer a tantalizing suggestion-clearly, the evidence here is far from conclusive-of very early Reformation agitation or conflict in Lindau, and well before the Edict of Worms (1521) had established the empire-wide ban on Luther's works. ${ }^{18}$ In sum, how one defines the Reformation chronologically as well as substantially

15. Peer Friess, for example, links them as follows: "Mit diesem Schritt [1528 abolition of the Mass] hatte sich Lindau für alle offenkundig und eindeutig gegen Papst und Kaiser gestellt und in einem Konflikt Position bezogen, der die einvernehmliche Kooperation der Bodenseeanrainer ebenso bedrohte, wie er die Einheit der abendländischen Christenheit als Ganzes gefährdete" (With this step [1528 abolition of the Mass] Lindau had openly and unambiguously stood against Pope and Emperor, taking position in a conflict threatening both the peaceful cooperation of residents of the immediate Lake Constance region, as well as the unity of all of western Christendom). Peer Friess, "Wider Papst und Kaiser: Lindau im Zeitalter der Reformation," in Die Reformation in Lindau, 17-42, 18.

16. Karl Wolfart, Geschichte der Stadt Lindau im Bodensee, 2 vols. (Lindau: Stettner, 1909), 1.1:263. This work is a useful overview and remains the standard reference for all local histories, despite the pronounced ideological character typical of such works; on which, see Martina Sterber, Ethnische Gewissheiten: Die Ordnung des Regionalen im Bayerischen Schwaben vom Kaiserreich bis zum NS-Regime (Göttingen: Vandenhoeck \& Ruprecht, 2010), esp. 94-95.

17. StAL, Annales Lindavienses, 419.

18. "Also ist Clas Schmidlin von wegensz Er schriben ussgesezt hat $\mathrm{dz}$ Im hoch verboten gewesen ist in Vangknuss komen und wider darauss gelossen hat och ain allt urfehd gesworn" (Likewise Claus Schmidlin was jailed for putting about writings, which had been highly forbidden him, and was released and also swore an oath [Urphed]). StAL, Ratsprotokoll (Rp) 1519-22, 2. 
(i.e., whether one emphasizes legislative over liturgical changes, or vice versa) alters the volume and quality of associated conflicts.

Which brings us, finally, to how one defines conflict itself, which is obviously an important methodological step in estimating its presence in any society, historical or otherwise. Again, the tendency has been to consider a very limited range of actions or events as indicating conflict of any sort. For example, Peer Friess has chosen a radically simplified metric approach, registering conflict on the basis of body count alone. Thus, he has concluded that the Lindau Reformation was conflict-free in comparison to Augsburg (where Anabaptists were executed) or Memmingen (where urban peasant sympathizers were killed in the wake of the Peasants' War) or Constance (where the military imposition of the Interim entailed heavy civilian casualties). ${ }^{19}$ While it is true that the body counts associated with religious conflicts in Lindau were relatively low (though not so low if one applies more expansive definitions of Lindau, or of the Reformation), the use of a very narrow-albeit also very precise-definition of conflict also risks obscuring very important historical dynamics. Indeed, even rudimentary sociological instruments, such as the notorious Conflict Tactics Scale (CTS) for the study of violence in family and other interpersonal settings, have long included non-lethal and non-physical indicators of conflict and measures of violence, such as verbal aggression. Furthermore, it is precisely the methodological occultation of the broader range of conflicts that has generated the myth of Lindau's conflict-free Reformation, which Moeller in turn thus considered a mysterious occurrence.

A comprehensive answer to the question posed in the title of this article is obviously beyond the scope of what follows. But it is in the spirit of such questioning that the actual evidence for conflict in the early Lindau Reformation is pursued below. That is, the purpose is not to establish or defend the Lindau Reformation, either partially or in its entirety, but rather more simply to understand it in common historical terms. The basic methodological and/or disciplinary assumption here is that historians cannot let the fact that there was a Reformation in Lindau stand as a generic mystery, any more than they should be convinced that a reforming spirit once dropped providentially from the heavens. What follows, therefore, is an attempt to recover three key dimensions of conflict in Lindau in the 1520s: 1) the discursive conflict of anticlericalism against the background of a strong Swiss-style congregationalist 
movement; 2) the violent social conflicts of the Peasants' War; 3) the symbolic conflict of iconoclasm in the context of established antipathy between Lindauers identifying as guildsmen and those who considered themselves patricians. Evidently, without consideration of these dimensions a historical understanding of the Reformation in Lindau remains elusive. The purpose, however, is not to suggest that the Reformation derived simply from division and conflict, any more than one would want these days to claim comprehensively that the Reformation was the primary cause of division and conflict in Christendom. Instead, it is the hope that from what follows conflict will be seen as integral to the Reformation. In Lindau in the 1520s, key conflicts-anticlericalism, the violence of the Peasants' War, and various iconoclasms-were part and parcel of processes we have come to call the Reformation. Yet, in the case of Lindau at least, it has become common, perversely, to see the forest of the Reformation without ever noticing the presence of all those trees.

\section{Some exemplary data}

\section{i) evangelical agitation}

According to the minutes of the Lindau council, on Friday before the feast day of St. Magnus in 1525, ${ }^{20}$ old Jerg Murer was released from jail on petition of his friends and relatives and following an oath binding him to the requisite agreement (Urphed [Urfehde]), according to which he would forgo revenge against members of the council, or anyone else, on account of his incarceration. ${ }^{21}$

Procedurally, the entry is quite unremarkable. Apparently, in a small community-and given its topography, parts of Lindau were undoubtedly claustrophobic-much of the council's energy was spent managing complex interpersonal relations and easing the inherent frictions of cheek-by-jowl living, which seemed ever on the verge of erupting into open conflict and bloody violence. Thus, the pages of the council minutes surrounding the record of Murer's release contain more or less lurid accounts of family violence, domestic tragedy, and even, occasionally, bedroom farce. Moreover, it is clear that council members struggled to stand entirely apart from those dramas to 
which the minutes of their deliberations bear witness. Indeed, the procedural correctness documented by the minutes almost certainly served to project a conceit of disinterestedness, something that was widely recognized as clever artifice rather than mere pretense. ${ }^{22}$ For example, Michael Endriss the hat maker was suspended from his council seat in early 1526 because Stephan Nükom had caught him at night with Nükom's wife. The record shows that Endriss had raised the woman as a daughter and had provided the dowry for her marriage to Nükom, and the implication is that the latter's outraged and violent response was quite warranted. Indeed, according to the record, Nükom was not punished for having threatened councilman Endriss, who took flight and was chased naked through the streets (though the minute-taker certainly described the scene in some detail). Instead, all three participants in the drama were banished from the city for attempting to resolve the conflict with a private arrangement, thereby circumventing and diminishing the council's authority as the sole arbiter of such conflicts in Lindau.

If this story sets a kind of benchmark for what one might call endemic interpersonal conflict (not enough is known of the economic and political capacities of all parties to call it "social" in any meaningful sense, though it was clearly "societal"), the minutes pertaining to Murer suggest other dimensions to that case, exceeding the normal range of human foibles and failures that generally kept the council busy. For one thing, the Murer case did not involve family relations per se. Instead, Murer had been incarcerated by order of the council for the following reasons: one Sunday (presumably a fairly recent one) after the sermon, when Herr Ulrich Lederhoss had exited the choir of St. Stephan's parish church and had entered St. Michael's chapel to read the Mass, Murer asked the priest when he thought he-addressed offensively as Pfaff-would have read Mass enough. Murer then further vowed that one of these days he would bash the chalice over the priest's head. Likewise, the record stated, Murer had scraped the image of his father's face from the St. Sebastian panel in St. Stephan's church ${ }^{23}$ further, he had grabbed a panel on the altar of

22. In this vein, Lindau also developed its very elaborate Ausstandordnung in this era; for more on which, see below.

23. "dz Er seins vatters angesicht In sant Stephans pfarkirchen In sant Sebastians tafel abgeschabd." StAL, Rp 1525-28, 4. It is unclear whether the image was of God the Father or whether Murer's worldly father had been portrayed in the manner of an extra in a scene, an honour commonly accorded prominent donors. 
the Franciscan church and had wrenched it about so that it had been broken. Finally, and for good measure, the minutes noted that Murer had committed other unspecified felonies (Frävel).

Since it involved uttering threats and committing violence against persons and properties, Murer's case fell squarely within the council's mandate to maintain peace and good order via criminal prosecution in Lindau's higher jurisdiction. The point of council competence and jurisdiction was emphasized by the mode of recording it as a quasi-familial conflict, a classification signaled by both the ambiguous identity of the injured father, as well as by the company of adjacent records of family violence in the volume of council minutes; notably, the record following that of Murer's case concerned Bastian Schnetzer's repeated assaults on his father. And yet, clearly the record also centred on symbolic actions that would soon come to be classified as distinctly religious-as so-called Religionssachen-by archivists and historians alike. Eventually, these matters might be identified as key indicators of the presence of reforming sentiments, or even as Reformation tropes: agitation for the abolition of the Mass; a particular strain of anti-clerical discourse, with special emphasis on eucharistic rituals, especially reserving the wine to the priesthood; the assault on images, which were both broken and defaced. All of these were wrapped up in the ominous threat of further violence, Urphed notwithstanding. The incident recorded by the council secretary-or, more precisely, the manner of its recording-thus captures something of an issue long ago identified with characteristic sharpness by Bob Scribner as a fundamental problem of theorizing the Reformation. For Scribner, the welcome prospect of a social history of the Reformation nevertheless posed a momentous historiographical challenge, precisely because it laid bare the theoretical problem associated with the Reformation's existence as an interpretive category, rather than as a historical event, or series of events. Thus, argued Scribner, it was insufficient to the task of writing an authentic (i.e., theoretically coherent) social history of the Reformation simply to frame or border-in the manner of an ornamental garden design - a received narrative of Reformation with a bit of the colour and texture of everyday life. Rather, the Reformation had to be re-conceptualized as a phenomenon or process that was inherently social, a proposition that continues to challenge certain non-confessional but nevertheless theological conceptions of human fortunes, 
including those distinguished by the imagination of "religion" as a unique and autonomous sphere of human action. ${ }^{24}$

As already indicated, Lindau was a relatively small city, even by the standards of the early sixteenth century. Yet it was home to a rich diversity of religious practices and institutions. In the story of local anti-clericalism, the context for the Murer case, two institutions stand out in particular: an aristocratic ladies' convent, known as the Stift, and the house of the discalced Franciscans, locally called simply the Barfüsser. The former enjoyed the status of a venerable foundation with imperial patronage. The Stift thus had a long history of competing for primacy with the actual civic establishments of the imperial city, which only intensified once the city established its identity as Protestant. Indeed, in the seventeenth century the precise legal relations between the city and the convent would become the subject of very baroque academic lawyering on a super-regional scale. ${ }^{25}$ Already in the early sixteenth century, however, the Stift's abbess had been compelled to accept Lindau citizenship, and the position of the city appears to have extended this circumstance to argue that the Stift as a whole bore the obligations of a corporate citizen. From our point of view, however, the Stift is important because it represented a certain kind of ecclesiastical privilege and constituted a distinctly alien presence in the city. This situation was, as Moeller recently observed, further exacerbated after the city opted decisively for reformed teaching and practice. This should not obscure the fact, however, that the convent, and especially the abbess and the priest retained as confessor to the Stiftsdamen, had long been the object of local criticism and ire well in advance of confessional dynamics. ${ }^{26}$ The Franciscan house, by marked contrast, served as a venue for the articulation and promulgation of, especially,

24. Bob Scribner, "Is There a Social History of the Reformation?" Social History 2 (1977): 483-505; compare Burton Mack, “A Radically Social Theory of Religion," in Secular Theories on Religion: Current Perspectives, ed. Tim Jensen and Mikael Rothstein (Copenhagen: Museum Tusculanum Press, 2000), 123-36.

25. Daniel Heider, Gründliche Außführung Wessen sich deß H. Reichs Stadt Lindaw wegen einer Ihro in anno 1626 abgelösten [...] Reichs-Pfandschafft [etc.] (Nuremberg: Endtner, 1643). At the heart of the legal dispute, however, there developed a significant source-critical or "diplomatic" debate: Hermann Conring, Censura Diplomatis Quod Ludovico Imperatori fert Acceptum Coenobium Lindaviense (Helmstedt: Henning Muller, 1672); Gerold Meyer von Knonau, "Das Bellum Diplomaticum Lindaviense," Historische Zeitschrift 26 (1871): 75-130.

26. Moeller, “Die Confessio Tetrapolitana," 60. 
arguments and sentiments in favour of a locally managed church, and against alien ecclesiastical interference. Already in the preceding century, the cathedral chapter of Constance, whose bishop exercised superior ecclesiastical jurisdiction in Lindau, had written to the Lindau council to complain about the sharp critical tone of sermons offered by the Franciscan Lesemeister. Yet, according to Friess, in Lindau such anti-clericalism was only "latent" and the situation in Lindau overall in the fifteenth century was "calm and stable." 27

By the early 1520s, however, the situation had actually become one of more open conflict. The then Lesemeister of the Franciscans, one Michel Hug, appears to have been something of a firebrand. Little is known of the content of his preaching on a regular basis; a single printed sermon from 1524 survives. That text is as clear in its evangelical orientation as it is direct in it indictment of the clerical establishment, concluding "thus did the greedy priests and monks all direct us to the saints, and make from them their purses." ${ }^{28}$ What Hug's printed sermon does not establish is the situation in which Hug's preaching took place, as part of a very public rhetorical running battle between himself and the parish priest of St. Stephan's, Johannes Faber. By the mid-1520s, Faber had in fact assumed duties in the episcopal administration in Constance and was thus rarely present in Lindau, where a vicar had been appointed. ${ }^{29}$ His

\section{Friess, 21.}

28. "Also haben uns die geyzigen und Münch alle auff die hailigen gewisen/und geltkauzen auß inen gemacht/Darbey Christi vergessen ist wordenn und im sein eer entzogen.” Michel Hug, Ain kurtzer aber Christlicher...Sermon, n.p.

29. Faber eventually became bishop of Vienna. The catalogue of his extant printed works runs to more than eighty titles, the best known of which include the early polemical intervention Joannis Fabri...opvs adversvs...dogmata Martini Lvtheri (1523) and the account/justification of the execution of Balthasar Hubmaier, Ursach warumb der Widerteuffer Patron vnnd erster Anfenger Doctor Balthasar Hubmayr zu Wienn...verbrennet sey (1528). To contemporaries, he was known as the "Hammer of the Heretics." He is also widely cited as either Johann or Johannes Fabri (the genitive is used in titles of his published works and also indicates that he was the son of a smith but did not practise the trade himself; his birth name was Heigerlin). The Allgemeine Deutsche Biographie and the Neue Deutsche Biographie shifted, without comment, from Faber (1881) to Fabri (1959). According to his biographer, Leo Helbling, O.S.B., Faber himself changed the manner of signing his name in the mid-1520s. Leo Helbling, Dr. Johann Fabri: Genaralvikar von Konstanz und Bischof von Wien, 1478-1541 (Münster: Aschendorff, 1941), 2n3. My thanks to Heiner Stauder of the Stadtarchiv Lindau for making this work available to me. In an effort to limit further confusion, I follow Lindavian primary and secondary sources in German, which call him Faber; admittedly, this usage may have been a deliberate insult, especially after Faber himself started to prefer Fabri. In English, see Denis R. Janz, "Johannes Fabri," in Contemporaries of Erasmus: A Biographical 
absenteeism was, of course, the subject of criticism; when Faber did come to Lindau for the celebration of the feast of Corpus Christi 1523, the sparks flew. Apparently, Hug met Faber's deliberately conservative sermon with a passionate counter-sermon. The latter apparently enjoyed widespread approval on the part of ordinary Lindauers. ${ }^{30}$ Consequently, the council issued a ban on the singing of libelous songs-the texts of which have, sadly, not survived-about Faber. ${ }^{31}$ When Faber lodged a suit against Hug at the episcopal court in Constance, however, the Lindau council refused to extradite Hug and chose to defend him instead. ${ }^{32}$ Faber thus found it prudent to avoid further visits to Lindau, where his vicar, Sigismund Rötlin, remained in charge. Apparently, the latter had adopted a decidedly evangelical stance by that time. For his part, Faber continued with various legal manoeuvres against the city well into the 1540s, long after both Hug and Rötlin had succumbed to the plague in the mid-1520s.

For various reasons, it is the legal aftermath of the Hug-Faber sermon battle that has dominated subsequent narratives. For one thing, because the legal case at Constance (and later at the imperial court) was an "external relations" matter, documentation was preserved in the city's correspondence archive (Reichsstädtische Akten). Thus, the emphasis on the adversarial ritual of litigation is, among other things, a function of the source situation. It is also the case, however, that the circumstances of Faber's appeal to episcopal and imperial instances motivated the Lindau council to suppress, as far as possible, internal dissent. Thus, one might also consider that a negative source transmission effect was at work, in addition to a positive one. Yet, while the council may have minimized the record of open conflict (and indeed, so laid the cornerstone for a myth of Lindau's pacific Reformation), that is not the same thing at all as actually preventing conflict. Indeed, as the case of old Murer suggests, the evangelical message preached in Lindau by Hug and Rötlin did

Register of the Renaissance and Reformation, ed. Peter G. Bietenholz, vol. 2 (Toronto: University of Toronto Press, 1986), 5-8; Jonathan R. Seiling, “The Political and Polemical Motives of Johann Fabri’s Moscouitorum Religio (1525-26)," The Catholic Historical Review 94 (2008): 653-70, and "Johann Fabri's Justification concerning the Execution of Balthasar Hubmaier," Mennonite Quarterly Review 84 (2010): 117-39.

30. StAL, Bertlin'sche Chronik.

31. K. Wolfart, 1.1:252; Albert Schulze, Bekenntnisbildung und Politik Lindaus im Zeitalter der Reformation (Nuremberg: Verein für Bayerische Kirchengeschichte, 1971), 14. Helbling all but ignores Faber's time appointed to Lindau. Janz and Seiling follow Helbling in downplaying the importance-at least for Faber-of his time in Lindau.

32. Friess, 24. 
resonate with at least some Lindauers; moreover, such resonance could and did entail both active confrontation and the threat of violence. Indeed, Friess speculates, quite reasonably and on the basis of comparison with other cities, that the council's primary motivation throughout its defense of the Faber suit was a fear of popular unrest. ${ }^{33}$ That is, notwithstanding the appearance of a legal case or diplomatic challenge, the entire Faber affair was in actuality a pragmatic effort-and sometimes urgently so-at internal conflict management. If one adds to Friess's comparative speculation the actual Lindavian evidence for vigorous congregationalist and anti-clerical agitation, the case is quite persuasive: the Lindau Reformation was in fact a creature of conflict and its management. Indeed, in 1528, even as the legal battles between Faber and the Lindau council were still escalating, the latter saw fit to punish one Jos Schlainz for blasphemy and uttering insulting words against the abbess. ${ }^{34}$ Why it did so, even as it was preparing to issue a city-wide ban on the celebration of Mass, can only be answered in relation to yet another field of conflict in Lindau.

\section{ii) The Peasants' War}

Between the time of Hug's passionate preaching and the prosecution of Schlainz, violent conflicts had, of course, wracked the whole region of Upper Swabia. In 1525-26, both the city of Lindau and individual Lindauers played a much larger role, it turns out, than is commonly recognized or acknowledged. Indeed, some recent modern histories still repeat the claim that Lindau was completely unaffected by the momentous events of $1525-26 .{ }^{35}$ This claim was a staple of the local and regional historiography of the nineteenth century, which in turn reflected official Lindavian protestations of innocence in various early modern proceedings, especially those immediately following the suppression of the peasants in $1525-26 .{ }^{36}$ It is clear from a range of sources, however, that

\section{Friess, 24.}

34. Rp 1527-29, 380.

35. “Die größte revolutionäre Entladung dieser Zeit ging in Lindau spurlos vorüber.” Schulze, 3.

36. In fact, over the course of the century following 1526, Lindau was beset by at least four serious crises pitting one politico-religious party against the other: during the Interim in the 1540s, over the suspension of a popular maverick pastor in the 1560s; during the Lindau Colloquium over Flacianism in the 1570s; and, most notably, over the introduction of auricular confession in 1626. 
many Lindau residents, both citizens and subjects alike, were deeply involved in the conflicts of 1525-26.

Most notably, when the local peasant assembly, the Rappertsweiler Haufen, first came together on 21 February 1525, the estimated eight thousand peasants gathered at a village just outside the boundary of Lindau's lower jurisdiction elected a Lindau citizen, the patrician Dietrich Hurlewagen, as their captain. Like many higher status citizens of Lindau, Hurlewagen did not actually reside within the city walls (in Lindau's case, on the island proper) but rather kept an estate on the mainland, near the Lindau-controlled village of Oberreitnau. Under Hurlewagen, the assembly twice plundered the monastery of Langnau. The second sack of Langnau is especially noteworthy, since it took place after Hurlewagen had apparently played a pivotal role in the negotiations of the Treaty of Weingarten in April of 1525. Elmar Kuhn claims that Hurlewagen convoked one thousand peasants for the second action against the monastery in order to dispel suspicions of his reliability which had started circulating among the peasants. ${ }^{37}$

The Rappertsweiler Haufen was only one of the bands that together formed the Lake Band or Seehaufen, which, along with the Baltringer and Allgäuer bands, came together in the super-regional peasant parliament convened at Memmingen. The Seehaufen, too, was led by a notable resident of Lindau's mainland territory, Jacob Humpis von Senftenau. Humpis came from a celebrated Ravensburg merchant family, but had himself fallen on hard times. His estate, located midway between the centres of two Lindau tributary villages (Kellnhöfe), Aeschach and Reutin, had been mortgaged in $1518 .^{38}$ Thus, two of the three most prominent leaders of the Seehaufen were actually Lindauers. It is hardly surprising, therefore, that when leading delegates of the Seehaufen came together in late June 1525 to draft a letter to the Swabian League protesting perceived breaches of the Treaty of Weingarten, their meeting place was Lindau. ${ }^{39}$ By that time, the Lindau council had already entered into what

37. Elmar Kuhn, “Der Bauernkrieg am See," in Seegründe: Beiträge zur Geschichte des Bodensees, ed. Dieter Schott and Werner Trapp (Weingarten: Drumlinverlag, 1984), 19-52, 30. For consideration of the Lindau evidence in particular, see Karl Schweizer, "Unser Begehren is, in Zukunft nicht mehr leibeigen zu sein!': Vom Bauernkrieg 1525 in Kreis und Stadt Lindau," in Jahrbuch des Landkreises Lindau 2000, ed. Andreas Kurz (Weiler: Verlag Holzer, 2000), 8-22.

38. Kuhn, 43. Senftenau is located about 15-20 minutes by foot from the Lindau city gates.

39. Kuhn, 30 . 
would become a protracted legal dispute with the neighbouring Counts of Montfort, in whose jurisdiction Rappertsweiler was actually located, over who had the right to punish peasant leaders. ${ }^{40}$ It is interesting, however, that neither of the Lindau personalities at the forefront of either band was ever effectively prosecuted. Indeed, Humpis was apparently rehabilitated almost immediately as the Bailiff of the Lindau Abbess, a position in which he was recorded as early as 1526 . Hurlewagen-or, more precisely, his wife-was involved in protracted property disputes, the council records of which indicate some sort of punitive forfeiture or confiscation. Hurlewagen himself, however, appears to have lived out his days in Switzerland.

Furthermore, the involvement of many lesser inhabitants of Lindau territory, who were subject to the lower jurisdiction of the city, is also a matter of record. Thus, the chronicle of the council secretary Johannes Bertlin, who was active in the second half of the sixteenth century, reproduced several pages of names of individuals from the Lindau jurisdiction who joined the peasants, indicating that they took the oath in the proper binding manner, with two fingers raised, and giving the muster location or Platz of the oath, terminology denoting also the lowest division in the organization of the peasants. ${ }^{41}$ That the participation of these Lindau peasants was well recognized at the time is further evidenced by records of legal actions taken against the city by property owners seeking damages for acts perpetrated by those subject to Lindau jurisdiction. ${ }^{42}$ Indeed, the minutes indicate that the council did compile evidence against known persons in the aftermath of the events. ${ }^{43}$

According to contemporary chronicle sources, as late as 1526 some four hundred peasants were reported to have assembled "not far from the city of Lindau," where a priest who was probably both the peasants' scribe and an evangelical preacher was apprehended and hanged by the Count of Montfort, from the very tree under which he had been preaching. ${ }^{44}$ Kuhn has suggested that this late assembly may have been a response to the renewed revolutionary call-to-arms issued by the Tyrolean Michael Gaismaier, who is known to have

40. Kuhn, 30 .

41. StAL, Bertlin'sche Chronik.

42. Rp 1525-28, 111-26.

43. Rp 1525-28, 253-59.

44. Franz Baumann, Quellen zur Geschichte des Bauernkriegs in Oberschwaben (Stuttgart: Literarischer Verein, 1876), 125; K. Wolfart, 1.1:265. 
sent written appeals to communities around Lake Constance. ${ }^{45}$ Finally, several chronicle sources recount the story of one Johannes Hüglin (also Heuglin), a priest of Sernatingen towards the western end of Lake Constance, whom the bishop of Constance had defrocked and executed by fire for heresy on 10 May 1526. All sources emphasize that Hüglin was a priest's son from Lindau, and that he had been actively preaching in the new evangelical manner. ${ }^{46}$

The evidence for Lindavian involvement in the conflicts of 1525-26 appears to be contradictory and even obfuscatory, but in no reading can it be taken as evidence for non-involvement. On the one hand, the Lindau council did in fact decline to throw its lot in with the local Haufen, as did also the councils of the somewhat larger cities of Ravensburg and Überlingen, with the latter displaying such early enthusiasm for repression of the peasants that the Swabian League requested restraint. ${ }^{47}$ Moreover, the collective citizenry of Lindau as represented by the council actually acted as a lord over the peasants in the lower jurisdiction, and thus one could well expect some conservative attitudes and postures within the city; certainly, much would have been lost materially by accession to the economic demands of the peasants. The assessment of the standard local history, on which Schulze's later evaluation of the Peasants' War as a non-event in Lindau is clearly based, thus stated the situation very carefully: the city's inhabitants remained calm throughout the upheavals of $1525-26 .{ }^{48}$ Indeed, technically, neither the peasants nor the citizen-patrician leaders from Lindau, for whose actions Lindau was clearly held responsible at the time, resided on the island proper but hailed, rather, from the mainland lower jurisdiction. Despite a certain limited correctness, however, the assessment is also historically misleading.

Therefore, at the same time as the Lindau council determined an official stance against the organized peasants, many who were subject to Lindau jurisdiction did support the movement, as is evidenced by both contemporary narrative sources and by administrative-investigative sources and litigation documents. These indicate a different kind of responsibility on the part of

45. Kuhn, 31.

46. The chronicles of Kröl/Thoman (reproduced in Baumann) and Bertlin. In later years, Heuglin's tale was and remains deployed in diverse Protestant martyrologies, regional revolutionary histories, and historical dramas.

47. Kuhn, 25.

48. K. Wolfart, 1.1:265. 
Lindau, including, possibly, a certain political complicity through citizens like Hurlewagen or Humpis von Senftenau. After 1526, defense against such claims of responsibility motivated a reemphasis of the difference between levels of jurisdiction and place of origin, which opposed diametrically the trend pursued by the council before 1525 . Before 1525 , the council was always keen to exaggerate the significance of its power in the lower jurisdiction, an obvious expansionist gambit that hinged on maximum blurring of the distinction between higher and lower jurisdictions, and served to push back against the likewise expansionist tendencies of the neighbouring counts of Montfort. The claims articulated immediately following 1525-26, that the city could not be held responsible for anything beyond the limits of its higher jurisdiction, would soon enough give way again to the old expansionism and competition with neighbours. For example, in 1535, the jurisdictional border contract with the counts of Montfort, mentioned above (see note 14), were once again confirmed. By the early seventeenth century, the massive survey and map commissioned by the council from the map-maker Andreas Rauch of Wangen ostentatiously advertised the extent of the lower jurisdiction and detailed all manner of extramural properties and other valuable or desirable features. ${ }^{49}$ Therefore, in practical reality Lindau was always much bigger than just the island/area within the city walls. Only after 1526 did it make tactical sense to claim otherwise ... and only for a limited period of time.

Revisiting the question of Lindau's involvement in the events of 1525-26 thus lays bare a structural rift and inherent conflict in Lindau, one which a particular historiographical approach has long functioned to conceal. For example, Schulze claimed that relative economic homogeneity meant that there were few grievances and little revolutionary agitation among Lindauers. This is only true, however, if one brackets entirely the mainland territories in accordance with the Lindau council's own legal defense and diplomatic

49. The production of the map did not go smoothly for a number of reasons and the city of Lindau ended up in protracted legal dispute with the mapmaker. While Lindau claimed that delays and escalating costs were due to Rauch's mismanagement of the project, Rauch claimed that he had faced opposition to his survey work on the mainland. A very detailed engraving produced on the basis of Rauch's survey in 1647 by Johann Morell, and entitled Veriüngter Abrisß, Deß Heyl. Reichs Statt Lindaw, und derselben theils Allieglicher, theils allein Nidergerichtlicher Oberkeit..., makes clear the purpose of detailing jurisdictions and properties on the mainland. A digital copy is available from the Staatsbibliothek Munich. Johannes C. Wolfart, Religion, Government and Political Culture in Early Modern Germany: Lindau, 1520-1628 (Basingstoke: Palgrave, 2002), 88-92. 
strategies. In actuality, there was considerable economic differentiation, which in turn corresponded to differences in legal status and political capacity. Conflicts ensuing from these differences, moreover, might find expression in the rhetoric of early reformers, which is very much in evidence in Lindau. Thus, the assessment of the appeal of Hug's evangelical preaching by the chroniclersecretary Johannes Bertlin - "that the common folk flocked to Michael Hug's sermons because these were something new"50-was and is misleading. In fact, the Rappertsweiler Haufen in particular had emphasized scriptural warrant for peasant demands, especially in a document that bears remarkable similarities to the better known Twelve Articles of Memmingen, but which it may have predated. ${ }^{51}$ This evangelical-political agitation may well account for the remarkable timing of changes to sacramental practice in Lindau's parish church in March of 1525, when communion was first offered there in both kinds (see above). Once again, Bertlin's explanation is insufficient from a modern historiographical point of view. For him, this key step-by some accounts the point of no return - was taken as a fulfillment of divine providence..$^{52}$ Yet none other than Moeller also considered the early introduction of reforming ideas and practices in Lindau as rather mysterious, albeit for somewhat different reasons. Famously, Moeller's focus was on the bounded urban community in its ideal form. Therefore, in 2007 Moeller concluded the same absence of conflict that the Lindau council wanted to advertise in 1526 (see above, esp. note 8). Of course, in actuality, the population of Lindau seen as a larger whole would have been sharply divided, both materially and ideologically, over the issues at the heart of the events of 1525-26. Put crudely, there were some Lindauers who identified as lords and some who identified as peasants. In retrospect, it is easy to hear only the lords (as did nineteenth-century historians) or to see only citizens/ burghers and no peasants (as did Schulze and Moeller). But even from the point of view of the council in March 1525, it was not at all clear who would eventually have the upper hand, much less whose victor's history would be written. It should come as no surprise, therefore, that it was at that very moment that the famously subversive religious practice of Utraquism carried the day. Moreover,

50. "Und weilen es etwas news war, ist vom gemeinen Volckh ein grosser zulauff zu Ime [Hug] worden, hat also die Evangelische lehr den anfang im barfusser Closter alhie genomen." StAL, Bertlin'sche Chronik.

51. Kuhn, 31.

52. StAL, Bertlin'sche Chronik. 
even a conventional dating of the start of the Lindau Reformation to the official suspension of the Mass by order of the council in 1528 should accommodate the fact that the council in 1525 saw fit to record precisely Murer's harsh words both against the Mass and against the chalice and the priest who wielded it under normal circumstances. The council immortalized this moment of conflict even as it released Murer in September of that year, and before the final major assembly of peasants in the immediate vicinity of Lindau.

Thus, one might re-situate the beginnings of the Lindau Reformation from the realm of divine intervention or historical mystery to the intersection of two domains of rational conflict. On the one hand, the Lindau council represented its citizens against an increasingly alien clerical presence, which in turn was represented by the remote and foreign episcopal authority in Constance. This conflict manifested itself especially in the discursive practice of anti-clericalism, which is clearly evidenced by the Lindau sources. No mystery there. On the other hand, the council's exercise of effective corporate lordship over a significant peasant population spread over a large mainland territory made it very much a target of religio-political demands which were wide-spread throughout Upper Swabia in the mid-1520s, and which most famously found precise expression in the Twelve Articles. Here, the situation as it evolved is somewhat more opaque. As seen, after 1525 the Lindau council was at pains to minimize the extent to which it controlled-and, hence, could be made responsible for-what happened on the mainland. Paradoxically, in practical terms it could maintain and even extend its influence over territory and peasants by further pursuing practical administrative reforms of pious endowments. In this regard, the council's authority was increasingly mediated via the endowments of the Lindau Spital, whose warden (Pfleger) by the later 1520 s reported directly to the Lindau council.

Together, these two domains of conflict constituted a very dangerous situation for the Lindau council, whose decision-making was habitually guided - it has been noted already—by fear of challenges to political authority and societal stability, from both without and within. Finally, however, it is clear that the elite that ruled Lindau was itself deeply divided. Over the course of the long sixteenth century, such division would issue in increasingly intense conflicts, culminating in the famous Neukomm Aufstand of $1626 .{ }^{53}$ But even at 
this very early stage of the so-called long Reformation, it is clear that differences between guild-based and patrician cliques constituted a third domain of conflict driving the processes of reform in Lindau.

\section{iii) guild-patrician conflict and iconoclasm}

In retrospect, 1525 was an extraordinary year for Lindau in many regards. It is also quite clear that contemporaries hardly knew what to make of it, or which way to turn. ${ }^{54}$ Thus, the same secretary who recorded the strong opinions of Murer in 1525 also recorded in 1526 that a city official suspected in the disappearance of half a barrel of salt in cross-lake transit from Schaffhausen had sworn an oath "to God an" (Zuo Got that the barrel had never been received..$^{55}$ Of course the standard formula of oaths addressed "God and the Saints." In 1526, however, the secretary appeared uncertain of how to proceed with respect to the status of the saints, by then the subject of both learned theological dispute, as well as more mundane and often quite practical controversies. Once again, however, the established narratives of the Lindau Reformation have tended to obscure levels of internal conflict over such questions as the appropriate attitude to the traditional saints, including the many physical representations or manifestations of these at locations throughout Lindau territory. Indeed, the palpable hesitation of the secretary is a rare hint that individual Lindauers were internally conflicted (assuming he was not writing with a Ratsherr or two looking over his shoulder) on such questions. Much more forcefully present is the evidence that Lindau was split along occupational and social lines on such key matters, with long-distance merchants and those either enjoying or aspiring to patrician status, all of whom tended to associate with the nonguild sodality of the Sünfzengesellschaft, squaring off against Lindauers who practised traditional trades and were organized into powerful guilds. And

Johnson (Basingstoke: Macmillan, 1998), 140-65; also, Wolfart, Religion, Government and Political Culture. Compare the chapter on the uprising in Mayr, 60-71, which reverts to an explanation based on the abrasive personality of Alexius Neukomm.

54. As Tom Scott has recently remarked, the full extent and complexity of the early Reformation still contains many problems and puzzles to be addressed. Tom Scott, The Early Reformation in Germany: Between Secular Impact and Radical Vision (Farnham, Surrey and Burlington, VT: Ashgate, 2013), esp. the introduction.

55. Rp, 1525-28, 211-12. 
yet, even here the full extent of the role of such social-structural conflicts-in driving reform of devotional practice and cultural pieties alike-is sometimes difficult to discern clearly from contemporary sources. Thus, for example, the patrician Bürgermeister Oswald Kröl recorded the removal of images from the parish church of St. Stephan's in a remarkably laconic tone. It is easy to see how one might conclude from his tone alone that the officially mandated removal of images in Lindau in 1530 had amounted to little more than an administrative loose end. According to Kröl, "In 1530, in March, they took away the altar pieces, images of the dear saints and all other paintings and on 15 June Zunftmeister (Guild-master) Job of the Smiths destroyed them completely."56 Indeed, following Kröl's lead, the subsequent historiography of Lindau has presented the removal of images as an act of overdue ecclesiastical hygiene, with no consideration of either the complex political dynamics or the cultural and ideological contradictions that inhered in what was in actuality a protracted phase of bona fide Bildersturm. ${ }^{57}$ For example, Kröl's account of the official removal is preceded in his chronicle by another description of what he considered out-and-out iconoclastic vandalism: "In 1529, in April, the wayside cross set up by Hans Griessbittel in 1516, and which had long worked many miracles, was irrevocably cut down and most wantonly demolished, [and] it was rumoured that Otmar Muoar, an Anabaptist, had done it." ${ }^{58}$ Though Kröl as an Altgläubiger disapproved of the removal of images in either case (as is suggested by the use of the veneration formula L.[ieben] hailigen), he was evidently especially repulsed by the wanton (wiest $=$ wüst) destruction of the wayside cross. It is not clear whether his reference to local rumours identifying the perpetrator as an Anabaptist was a further point of outrage, or whether it

56. “Ao 1530 in Martij, hatt man die Alter bilder unnd gemelt der L. hailigen auch alle tafflen hinweckh gethon auff 15 Junio zerhiew se gar Zunfftmaister Job zu Schmiden.” StAL, Kröl'sche Chronik.

57. The literature on Reformation-era iconoclasm is vast, but exemplary critical engagements with iconoclasm, iconoclastic/iconoclastic-like acts, and even pseudo-iconoclasm can be found. See Christopher Wood, "In Defense of Images: Two Local Rejoinders to the Zwinglian Iconoclasm," Sixteenth Century Journal 19 (1988): 25-44; Thomas Kaufmann, 'Der Schriftaltar' in der Spitalskirche zu Dinkelsbühl - ein Zeugnis lutherischer Konfessionskultur," Archiv für Reformationsgeschichte 103 (2012): 117-48. On Lindau, see Gudrun Litz, Die reformatorische Bilderfrage in den schwäbischen Reichsstädten (Tübingen: Mohr Siebeck, 2007), 63-75.

58. “Ao 1529 Im Aprill wardtt dz Kreitz vor strass, so Hannss Griessbittel Auffgericht Anno 1516 unnd lanng vil wunder zu dem gethan hatt, zulledst abgesegett, und wiest zerhawen, war die sag Otmar Muoar Ein Widertäuffer het es gethon." StAL, Kröl'sche Chronik. 
rather served to mitigate Lindavian ownership of the horrible event. Certainly, that is how later historiography has interpreted the matter, emphasizing that local Anabaptists, though they eventually did re-baptize several Lindauers, had initially arrived from Augsburg and were thus really an alien presence. ${ }^{59}$

Still, iconoclastic controversy itself was very much at home in Lindau, with sharp differences of opinion on the tolerability of images and their various uses accompanying marked conflict. This conflict, moreover, seems to have followed established social cleavage lines. Indeed, from a contemporary perspective, such conflict was highly predictable, which is undoubtedly a major reason why the council pursued an official removal of images in 1530, following the unsanctioned actions by Murer and Muoar. ${ }^{60}$

Yet, it turned out that even a council-sanctioned image removal could not forestall such conflict entirely. Thus, the Zunftmeister of the Smiths' guild, one Job Nesar, clearly took a much broader view of his mandate as the executor of the council's removal order than did other leading councillors, especially Bürgermeister Calixt Hünlin. According to Kröl, the altar pieces, statues, and paintings had been removed at the end of March. It was not until June 15, however, that a crew from the Smiths' guild, led by Zunftmeister Nesar, chopped them up and burned them. Is it possible that in the intervening months the council had debated the precise nature, extent, purpose, and so forth of Lindavian iconoclasm? It is not only possible, but highly likely. Indeed, the chronicler and city secretary Johann Bertlin reported (writing later in the century) that Zunftmeister Nesar had pursued the destruction of altarpieces, statues, and paintings on account of his exceptional zeal: aus sondern [sic] eifer. Bertlin further indicated that a stand-off had actually taken place during the removal, between Zunftmeister Nesar and Bürgermeister Hünlin. In fact, Bertlin reported that the valuable new organ in St. Stephan's could only be preserved from the same fate as the images by the desperate intervention of the Bürgermeister. ${ }^{61}$ It appears that the confrontation between Nesar and Hünlin issued in something of a feud between the two, which was then played out in, among other places, the arena of the council chamber (more on which

59. K. Wolfart, 1.1:269.

60. Litz, in Die reformatorische Bilderfrage, sees no evidence that the removal of the images was actually ordered or sanctioned by the Lindau council. Nevertheless, the circumstantial case seems very strongall the more so in contrast to the official response to unsanctioned acts.

61. StAL, Bertlin'sche Chronik. 
below). Notwithstanding the considerable body of evidence for debate, conflict, and, ultimately, very dangerous open confrontation over the organ, Schulze maintained the conventional characterization of the Lindau iconoclasm as a carefully managed affair, one that did not entail conflict in its origins and execution, but rather succeeded in averting it.

That is certainly not how contemporaries viewed the matter, however. In 1534, when the council deliberated the removal of idols and statues (götzen und pilder) in a subsidiary of St. Stephan's parish in the mainland village of Reutin, it was determined to detail council-appointed finance officers (Stüblinsleut), who were explicitly instructed to manage the removal in a quiet and orderly manner. ${ }^{62}$ In 1534, the memory of the stand-off between Nesar (and his lusty Smiths) and the Bürgermeister Hünlin was undoubtedly still very fresh. Indeed, shortly preceding the order for the removal of the idols in Reutin, the council secretary recorded a libel case in which one Jos Huober had criticized a Bürgermeister Bodmer for his negotiations at the diet of Augsburg. These, Huober was alleged to have stated, had been conducted without a proper mandate from the council, with the result that Bodmer had returned from Augburg with a pig of a deal (ain saw bracht). Huober was jailed but subsequently released, according to the council minutes, by the grace and mercy of the council (though, it was noted, he certainly deserved great punishment), in consideration of his advanced age and on the vigorous interventions of the honourable Smiths' guild, as well as those of his friends and neighbours. Huober was also required to apologize to Bodmer and to swear an Urphed that included an undertaking henceforth to adhere diligently to the Word of God, its preachers, and his Obrigkeit, and to refrain from all similar libels and defamations. ${ }^{63}$

While one would not want to rule out the possibility that the aged Huober had criticized what Bodmer brought back from Augsburg from the perspective of an Altgläubiger, the intervention of the Smiths' guild, the same guild led by the zealous idol-smasher Job Nesar, suggests otherwise. Rather, it seems that members of this guild harboured religious views that they felt were being compromised or betrayed by an inner circle or clique that dominated Lindau government. The council minutes indicate that as early as 1531, the council had jailed several outspoken critics of the religious diplomacy pursued by

62. Rp 1532-51, 43.

63. Rp 32-51, 32b-33. 
the leading officials. Unfortunately, the guild affiliation of those jailed is not known. Still, it is likely that they were guildsmen, rather than patricians, who criticized those elite members of council (in this period usually a Bürgermeister; by the end of the century, more commonly a city syndic) normally detailed for diplomatic missions. Indeed, an atmosphere of general or combined politicoreligious reform had already led to the introduction of constitutional reforms in 1529, changes that increased the representation of guildsmen, while reducing patrician influence. ${ }^{64}$ Thus Schulze has concluded that while economic divisions were not much in evidence in Lindau, there were signs of deep political rifts and rivalries. These corresponded to tensions between "hotter" reforming elements among the guildsmen and "cooler," more cautious, or even conservative elements in merchant and patrician circles. This situation is further indicated by the marked tendency of the council in these years to put potentially controversial or inflammatory decisions to a full commune. In this context, the formula Radtt und Gemaindtt In Lindow ains wordten, with which Kröl noted the official decision to abolish the Mass throughout Lindau territory in July 1532, appears less as rote and more as the communication of a significant and historic moment of agreement, against the backdrop of a bifurcated political establishment and a political process that was normally adversarial. In other words, the Reformation may well have issued in considerable conflict; it certainly did so in Lindau as it did in many, many other places. More importantly, however, it also arose from manifold conflicts. In Lindau, these included conflicts arising from the structures and practices of late medieval religion, those issuing from deep differences in the basic conditions of existence and capacities to change the same, and those that inhered in the very peculiar political cultures of cities like Lindau. Indeed, local political culture was already explicitly suspected as a major reason for the success of the Reformation in places like Lindau by Charles V, which is why his Carolina countermanded Lindau's local constitutional adjustments of 1529 by abolishing the Zunftregiment altogether, at least in theory.

\section{Conclusions}

The mythogenesis of Lindau's conflict-free Reformation has been presented above as a relatively elementary matter of definitions, albeit in all three aspects 
of the topic. From a historiographical point of view, moreover, the establishment of a magisterial evangelical church in Lindau during that heady first phase of the Reformation in south Germany is-pace Moeller-not even remotely mysterious. However, the concept of myth animating the above discussion is far from elementary, far exceeding a commonsense understanding of myth as some sort of "false" or "primitive" history. Rather, myth is understood here as something that is promulgated and propagated by folk who possess all the same capacities as modern professional historians, and who chose a mythical account in conformity with, or in pursuit of, certain interests. Thus, it is entirely conceivable that the very same individual can function sometimes as Reformation mythographer, and sometimes as Reformation historiographer. Furthermore, successful myth realizes the power of mythographers who, in turn, are strongly motivated to curate their myths. For this reason alone, one expects, the myth of Lindau's conflict-free Reformation will be fairly impervious to historical or historiographical criticism. For example, it probably will make little difference to point out that the common conclusion of peaceful and harmonious social relations in Lindau is based on the evidence of an absence of recorded conflict. Apart from the logical deficiency of such reasoning, the source situation for the 1520 s is simply too haphazard to conclude anything on the basis of the "shape of the sources" (i.e., Quellenlage). In the years 1522-24, especially, the ravages of plague meant that official record keeping in Lindau was significantly disrupted. Furthermore, there is good reason to believe that certain records of the early Reformation in Lindau were subsequently purged from the archives by Lindauers themselves, who were keen to obscure the specifically Tetrapolitan (i.e., not aboriginally Lutheran) dimensions of their history. ${ }^{65}$

Nor will it probably matter either to identify general cultural propensities for conflict in Lindau, or to suggest that in the 1530s and 1540s Lindauers displayed a veritable preoccupation with pro-active conflict management. The substitution-probably well-advised-of council servants for members of the Smiths' guild as official iconoclastic agents is but one example of such preventative foresight. ${ }^{66} \mathrm{~A}$ very different conflict prophylaxis is represented by the revised anti-nepotism measures (Ausstandsordnung) introduced by the council

65. Johannes C. Wolfart, "Sex, Lies, and Manuscript: On the 'Castration' of the Lindau Archives," in Shell Games: Studies in Scams, Frauds, and Deceits (1300-1650), ed. Mark Crane, Richard Raiswell, and Margaret Reeves (Toronto: Centre for Reformation and Renaissance Studies, 2004), 271-85.

66. Rp 1532-51, 43. 
in 1542 , to prevent "confusion" on account of bonds of friendship or relation. ${ }^{67}$ Together, such examples suggest that Lindauers looked back on the conditions of the 1520s as somehow outstanding, even when viewed against a background of high levels of normal conflict. A considerable irony of Lindau's early adherence to the Tetrapolitana is that by the 1530s the survival of the city's imperial privileges depended on the legitimacy of council rule (i.e., Obrigkeit and Regiment), a legitimacy founded entirely in a public projection of ability to maintain peace and good order. The management of conflict thus became a strategic necessity for the maintenance of Lindau's position within the imperial framework.

Keeping up appearances in this regard was no mean task. Everyday interpersonal relations in Lindau entailed considerable conflict; what is more, culturally they were conceived in such terms. For example, the continued use of the alt Urphed formula-despite the fact that Lindau, unlike other jurisdictions, did not keep a designated Urfehdebuch-indicates a general expectation of vengeance in the context of an "economy of honour." ${ }^{68}$ Local conflict-happiness was further institutionalized in the feud in Lindau, which was alive and well in the 1520s. For example, in 1520 a citizen of the city of Ravensburg sued Lindau for what was in effect a breach of contract, because Lindau had failed to come to the aid of one of Ravensburg's citizens in a feud. ${ }^{69}$ The exchange between Ravensburg and Lindau, which was eventually adjudicated by the city of Überlingen, fits a well-established pattern of the feud as both a recognized legal process and a vibrant cultural practice. ${ }^{70}$ The cultural importance of the practice is established, further, by the use of the feud in Lindau-internal relations. An especially interesting example is that provided by the feud conducted between Bürgermeister Calixt Hünlin and Zunftmeister Job Nesar in the aftermath of their confrontation over the removal of images/idols-and, especially, what constituted the latter-from the parish church of St. Stephan's. In this instance, moreover, the ritual conflict of the feud was harnessed to the emerging processes of magisterial reform in Lindau. Though there were clearly multiple dimensions

67. “In ainem Rath von wegen der aussteeung freundschaffthalben Irrung zugetragen [...].” Rp, 1532-51, 117.

68. For a recent discussion of this concept, see Peter S. Baker, Honor, Exchange and Violence in Beowulf (Cambridge and Rochester, NY: D.S. Brewer, 2013), esp. ch. 2.

69. StAL Reichstädtische Akten (RA) 56, 4.

70. For overview see Hillay Zmora, The Feud in Early Modern Germany (Cambridge: Cambridge University Press, 2013), esp. ch. 1. 
to the antipathy between the two men, council minutes indicate that, following the standoff over the organ in St. Stephan's, the two carried on a feud that was eventually resolved officially by order of the council on 4 April $1533 .{ }^{71}$ Finally, if the majority of Lindauers probably did not engage in formal feuds, many more of them regularly engaged in the likewise ritual confrontation of taking a case before either the city court or the council for adjudication. While it was common for people to have representation (Fürsprech) in this adversarial process, not until the end of the century did it become the practice for such representation to be carried out by professional lawyers. It is hardly surprising, therefore, that the Lindau records are replete with admonitions to steer clear of faction (Uneinigkeit), or with attempts to reconcile parties (Parthyn), as well as with declarations of unity (Einigkeit).

Clearly, such invocations of unity and declarations of peace were anything but statements of fact concerning the social-political situation on the ground. Instead, they were more or less self-conscious fictions, myths one could reasonably place somewhere on a scale running from administrative wishful thinking to politically motivated dissimulation. Once again, the rich records of Johann Faber's conflict with both the council and with his (ex-)parishioners provide a vivid example of such creative inventions. At one point, Faber sued Lindau for declining to provide him with a guarantee of safe passage in the city. The council responded that they had not issued such a guarantee because he did not need one; moreover, it was not the Lindau custom to issue such guarantees. When Faber secured an imperial order instructing Lindau to grant Faber safe passage in its jurisdiction (and which certainly reads like he needed protection), the council replied in language larded with all the usual claims of unity and peace. At the same time, however, Lindau's response to the imperial order also clarified that the council was simply not in a position to guarantee safe passage. According to the council, Faber was so hated in Lindau that if he pursued his plan to come and preach in Lindau, he would upset the common man and subvert established authority. ${ }^{72}$

71. 1532-51, 21. Also, Schulze, 26.

72. "Darumb und Dieweil Auß sollichen seinen predigen nichts dann Auffrur emporung und widerwillen des gemeinen mans gegen der obberkeit zu forchten unnd zu besorgen ist [...]." StAL RA 63, 1. 